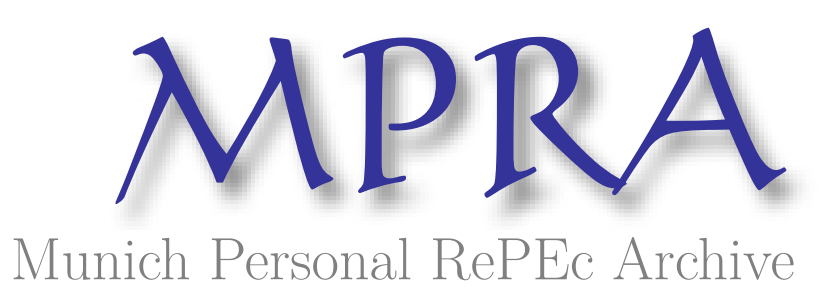

\title{
The evolution of Ukrainian economy: new trade theory evidence
}

Konchyn, Vadym

26 October 2006

Online at https://mpra.ub.uni-muenchen.de/34328/

MPRA Paper No. 34328, posted 26 Oct 2011 14:16 UTC 


\title{
EVOLUTION OF UKRAINIAN ECONOMY: NEW TRADE THEORY EVIDENCE
}

\author{
Vadym Konchyn \\ Kyiv Institute of Business and Technologies \\ 41/43, Belitskaya Str., 04078, Kyiv, Ukraine \\ Tel: +38 (067) 7731916 \\ e-mail: onwad@yahoo.com
}

Vadym Konchyn, $\mathrm{PhD}$ in International Economics, Associate Professor, Chair of Finance, Kiev Institute of Business and Technologies.

This article was prepared during my teaching in Ternopil State Economic University (Ukraine), Chair of International Economics, Financial and Credit Relations, and Marketing (March-June, 2006). English version proof-reader Tetyana Shpak (Journal of European Economy, Ukraine). 


\section{Introduction}

As the contradictions of capitalistic production increase and globalization processes proliferate, the economic principles of industrial and investment activity and international trade are going through continuous transformation. Even though the rule of comparative advantage remains important in explaining business motives at both national and trans-national levels, it is unable nowadays to reflect the whole palette of economic phenomena and processes that predetermine the development of the leading industrial countries and big multinational corporations.

At the close of $20^{\text {th }}$ century originated a qualitatively new international trade paradigm peculiar to advanced industrial countries. On the one hand, advanced industrial countries and their multinational corporations in their cooperation with developing and transition countries follow the traditional trade theory principles. On the other hand, the industrial and trade relations between the advanced countries themselves take on a different format. It is characterized by the development of international intra-industry specialization, the basis of which consists in differentiated capital- and R\&D-intensive goods, deepening trade (economic) integration, strengthening industrial and sales positions of transnational corporations of advanced countries on the domestic and foreign markets. These processes made for the appearance of a new fundamental theoretical and empirical research, which underlay the formation of the New Trade Theory.

This problem takes on special significance in examining the progress of Ukraine on its way to market reforms and European economic integration. Proceeding from the experience of Central and Eastern European countries (CEEC), the processes of Ukraine's economic liberalization and approximation of its level of economic development to that of the EU-members should stipulate for transition of the national economy onto the dimension which explains industrial and trade relations through the prism of the New Trade Theory postulates coupled with Traditional Trade Theory principles.

\section{New Trade Theory in Explaining Actual Economic Processes in Global Economy}

New Trade Theory evolved with the works of Krugman (1979) and Helpman and Krugman (1985), who assumed that international trade between countries with similar factor proportions occurs mainly in differentiated varieties on the basis of increasing returns to scale (increasing scale economies). These basic principles cannot fit within the traditional neoclassical models of the Heckscher-Ohlin theory postulating the development of inter-industry trade between countries a result of differences in their relative factor endowments.

New Trade Theory focuses primarily on the problems of international industrial specialization of advanced countries, convergence of their industrial 
and demand structures, as well as development of the international trade among advanced countries which has taken on an intra-industry character during the past three decades (Falvey (1981), Aquino (1978), Balassa (1986), Bergstrand (1983), Fontagné and Freundenberg (1997)).

Besides, close attention is paid to the increasing role of transnational corporations in global economy and their impact on the evolution and nature of international specialization of the developed, developing and transition countries (Markusen (1984, 1998), Markusen and Maskus (1999), Muchielli and Burgenmeier (1991), Brainard (1993), Brenton et al. (1999), Ekholm (1997)). Today, nearly 93\% of total world FDIs falls on the share of multinational corporations (MNCs) of the developed industrial countries, 25\% of which is a share of American MNCs and 55\% -- of the MNCs of EU-15 origin. Throughout recent years, FDI outflows from the EU-15, USA and Japan have been growing faster than their international trade. In 1993-2003, the average growth of FDIs from these countries made $15.9 \%$ compared to average growth of their international trade of $6.7 \%$ (in 1993-1999 - 30.9\% and 7.5\% respectively) ${ }^{1}$. This trend shows that during the last decade, the growth of economic activity in advanced industrial countries and global economy as a whole was primarily driven by the investment component (See Tables 1 and 2).

Table 1. Total FDI (Inflows + Outflows) Growth in the Global Economy, 1994-2004.

\begin{tabular}{|c|c|c|c|c|c|c|c|c|c|c|c|}
\hline \multirow[t]{2}{*}{ Regions } & 1995 & 1996 & 1997 & 1998 & 1999 & 2000 & 2001 & 2002 & 2003 & 2004 & $\begin{array}{l}1995- \\
2004 * *\end{array}$ \\
\hline & \multicolumn{10}{|c|}{ Cumulative Total FDI (Inflows + Outflows) Growth, 1994=1 } & $\begin{array}{l}\text { Average } \\
\text { Total } \\
\text { FDI } \\
\text { Growth, } \\
\%\end{array}$ \\
\hline World & 2.30 & 3.58 & 5.33 & 7.79 & 11.93 & 16.85 & 19.99 & 22.72 & 25.21 & 27.97 & 14.56 \\
\hline Europe & 2.41 & 3.68 & 5.37 & 8.36 & 14.12 & 21.23 & 25.03 & 28.73 & 32.11 & 34.53 & 17.11 \\
\hline $\begin{array}{l}\text { North } \\
\text { America }\end{array}$ & 2.24 & 3.50 & 5.32 & 7.88 & 11.58 & 15.53 & 18.09 & 19.92 & 21.38 & 24.06 & 16.17 \\
\hline $\begin{array}{l}\text { Central } \\
\text { and Latin } \\
\text { America }\end{array}$ & 2.18 & 3.88 & 6.63 & 9.38 & 13.42 & 16.81 & 18.99 & 20.89 & 22.73 & 25.45 & 15.11 \\
\hline CIS* & & & & 1.29 & 1.66 & 2.00 & 2.39 & 2.90 & 3.94 & 5.27 & 21.85 \\
\hline Asia & 2.17 & 3.35 & 4.70 & 5.75 & 7.02 & 8.84 & 10.29 & 11.55 & 12.67 & 14.82 & 12.11 \\
\hline Middle & & & & 1.26 & 1.52 & 2.04 & 2.42 & 2.79 & 3.07 & 3.55 & \\
\hline
\end{tabular}

${ }^{1}$ Calculated by author on the basis of data from OECD International Direct Investment Database. 


\begin{tabular}{|l|l|l|l|l|l|l|l|l|l|l|l|}
\hline East* & & & & & & & & & & & 11.02 \\
\hline Africa & 2.26 & 3.48 & 7.15 & 9.62 & 15.38 & 19.70 & 27.12 & 32.43 & 40.11 & 48.44 & 39.58 \\
\hline
\end{tabular}

Notes: $* 1997=1$.

** For CIS and Middle East average total FDI growth is calculated for 19982004 on the basis of growth to previous years.

Source: author's calculations based on UNCTAD World Investment Report 2005.

Table 2. Growth of International Trade in Goods and Services in the Global Economy, 1994-2004.

\begin{tabular}{|c|c|c|c|c|c|c|c|c|c|c|c|}
\hline Regions & 1995 & 1996 & 1997 & 1998 & 1999 & 2000 & 2001 & 2002 & 2003 & 2004 & $\begin{array}{l}1995- \\
2004 * *\end{array}$ \\
\hline & \multicolumn{10}{|c|}{$\begin{array}{l}\text { Cumulative Growth of International Trade in Goods and Services, } \\
\qquad 1994=1\end{array}$} & $\begin{array}{l}\text { Average } \\
\text { Growth } \\
\text { of } \\
\text { Interna- } \\
\text { tional } \\
\text { Trade } \\
\text { in Goods } \\
\text { and } \\
\text { Services } \\
\%\end{array}$ \\
\hline World & 2.18 & 3.43 & 4.72 & 5.99 & 7.33 & 8.81 & 10.26 & 11.77 & 13.52 & 15.64 & 8.04 \\
\hline Europe & 2.21 & 3.46 & 4.72 & 6.05 & 7.39 & 8.80 & 10.22 & 11.72 & 13.53 & 15.67 & 8.19 \\
\hline $\begin{array}{l}\text { North } \\
\text { America }\end{array}$ & 2.11 & 3.31 & 4.63 & 6.00 & 7.49 & 9.20 & 10.82 & 12.44 & 14.17 & 16.15 & 7.25 \\
\hline $\begin{array}{l}\text { Central } \\
\text { and Latin } \\
\text { America }\end{array}$ & 2.20 & 3.46 & 4.87 & 6.27 & 7.58 & 9.07 & 10.52 & 11.88 & 13.36 & 15.22 & 6.88 \\
\hline CIS* & & & & 1.85 & 2.59 & 3.52 & 4.51 & 5.61 & 6.97 & 8.78 & 10.27 \\
\hline Asia & 2.20 & 3.45 & 4.74 & 5.88 & 7.12 & 8.58 & 9.94 & 11.40 & 13.09 & 15.21 & 8.40 \\
\hline $\begin{array}{l}\text { Middle } \\
\text { East* }\end{array}$ & & & & 1.93 & 2.98 & 4.32 & 5.60 & 6.93 & 8.49 & 10.45 & 10.91 \\
\hline Africa & 2.17 & 3.39 & 4.66 & 5.84 & 7.05 & 8.40 & 9.73 & 11.09 & 12.76 & 14.89 & 8.31 \\
\hline
\end{tabular}

Notes: $* 1997=1$

** For the CIS and the Middle East average total FDI growth is calculated for 1998-2004 on the basis of growth to previous years.

Source: author's calculations based on data of International Trade Statistics WTO 2005. 
At the same time, the commodity production of MNCs substituted for national commodity production in Europe, Northern, Central and Latin America, Africa, and the Commonwealth of Independent States (CIS) (See Table 3). In this context, the model of Markusen and Venables (1998) demonstrates how economic integration between advanced industrial EU-countries leads to convergence of their economic sizes, as well as to equalization of their relative factor endowments and production costs. This induces companies of advanced countries to both use the increasing returns to scale and look for new production locations with comparative advantage and outlets abroad. As a result of such strategies, the activity of transnational corporations substitutes for international trade in goods and services produced by national companies.

Table 3. FDI Inflows to Regions as a Share of GDP, \%

\begin{tabular}{|c|c|c|}
\hline Regions & 1994-1999 & $2000-2004$ \\
\hline World & 1.8 & 2.7 \\
\hline Europe & 2.3 & 4.7 \\
\hline North America & 2.6 & 8.0 \\
\hline Central and Latin America & 3.3 & 3.4 \\
\hline CIS & 1.4 & 2.2 \\
\hline $\begin{array}{l}\text { Asia } \\
\text { of which }\end{array}$ & 1.2 & 0.7 \\
\hline New Industrial Countries & 1.8 & 1.6 \\
\hline Japan & 0.19 & 0.17 \\
\hline Middle East & 1.16 & 1.15 \\
\hline Africa -51 countries & 1.0 & 7.0 \\
\hline
\end{tabular}

Source: author's calculations based on statistical data of the IMF and UNCTAD (2005).

Table 4. FDI Inflows to and Outflows from Regions as a Share of GDP, \%

\begin{tabular}{|c|c|c|}
\hline Regions & 1994-1999 & $2000-2004$ \\
\hline World & 3.6 & 5.6 \\
\hline Europe & 5.8 & 9.9 \\
\hline North America & 5.5 & 12.6 \\
\hline Central and Latin America & 3.5 & 4.0 \\
\hline CIS & 1.7 & 3.3 \\
\hline $\begin{array}{l}\text { Asia } \\
\text { of which }\end{array}$ & 1.7 & 1.8 \\
\hline New Industrial Countries & 2.5 & 2.8 \\
\hline Japan & 1.6 & 0.9 \\
\hline Middle East & 1.2 & 1.3 \\
\hline Africa -51 countries & 1.2 & 7.3 \\
\hline
\end{tabular}

Source: author's calculations based on statistical data of the IMF and UNCTAD (2005). 
The New Trade Theory initiates a discussion about the static and dynamic advantages (gained within the traditional neoclassical theory only under free trade and accelerated economic liberalization) a country achieves under imperfect competition (Krugman, 1985) and interventionist economic policy (Bhattacharjea (1995), Anderson and Neary (1996), Brainard and Martimort (1997), Eaton and Grossman (1986), Fuerst and Kim (1997)).

In the traditionally neoclassical sense, gains from international trade -- as a source of economic growth -- are maximized through adjustment, by means of economic liberalization of the uneven factor and resource re-allocation generated by the interventionist industrial policy at the domestic market with the goal of import substitution or export orientation.

In the process of deepening economic liberalization and intensifying functional market competition (Fritsch et al., 2003), which is in fact a prototype of perfect competition, the production factors and resources start to move inside the country from inefficient to efficient industries, thus ensuring optimal development of the economic system and international trade. Gains from trade are reflected as a comparative advantage based on differences in relative factor endowments and production technologies between the countries and revealed perfectly under free trade.

Gains from international trade within the scope of New Trade Theory are generated and maximized when firms increase their production facilities and consolidate through mergers and acquisitions (M\&A) in order to rationalize production, reduce average costs and thus achieve better positions on the foreign markets. These steps become an objective necessity for the firms of advanced industrial countries in the Old economy because of the overproduction problem conditioned by highly differentiated consumer demand.

Hence, the rationale behind gains from international trade is not the comparative advantage any more, but the increasing returns to scale. For the firms to realize increasing returns to scale, a country should provide open economy conditions, including international competition on the domestic market. However, when firms achieve their increasing returns to scale, the imperfect competition appears. The market structure acquires properties of monopolistic competition, with free market access and international trade in goods differentiated by price and quality. The dominant positions on the monopolistic market with high competition belong to MNCs because they own substantial financial resources and international channels of technology development, and are better able to carry out R\&D activities and elaborate a new differentiated product for consumers. Under monopolistic competition, the effect of internal increasing returns to scale is generated when production unit costs depend on the firm's size. Average cost reduction effects under increasing returns to scale can be described with the following equation:

$$
\mathrm{TC}_{\mathrm{X}}=\mathrm{FC}+\left(\mathrm{VC}_{\mathrm{X}}\right) \mathrm{X} \text {, }
$$

where $\mathrm{TC}_{\mathrm{X}}$ - total costs, $\mathrm{FC}$ - fixed costs, $\mathrm{VC}_{\mathrm{X}}$ - variable costs, $\mathrm{X}$ - output. Consequently, average production costs are equal to $\mathrm{TC}_{\mathrm{X}} / \mathrm{X}$. The larger the 
production scale gets, the smaller the average production costs are, given variable costs are constant:

$$
\mathrm{AC}_{\mathrm{X}}=\mathrm{FC} / \mathrm{X}+\left(\mathrm{VC}_{\mathrm{X}}\right)
$$

where $\mathrm{AC}_{\mathrm{X}}$ - average production costs.

The market structure can also be characterized as oligopolistic when several companies determine the situation on the market (in certain industry) by setting arrangements among themselves concerning prices of differentiated and homogenous goods or their volumes.

Under monopolistic and oligopolistic competition, the international trade is based on various foreign market penetration strategies used by consolidated companies. Various forms of production and trade transnationalization become an essential element in the activity of big companies of the advanced countries and require that these companies look for efficient mechanisms for foreign market penetration and consolidation of positions on these markets, in particular by means of close cooperation with governments of the countries that act as recipients of transnational activity.

The development of imperfect competition can create difficulties for market access and/or functioning of new firms in the markets, lead to unfair business practice, and increase the "race to the bottom" effects. These problems, on the one hand, can weaken the entrepreneurship initiative, while on the other, negatively affect the conditions of work and welfare of workers as final consumers.

Hence, in view of the modern tendencies in the development of international trade in global economy and transformation of its paradigm for advanced industrial countries, one should distinguish four main modifications of the neoclassical basics of international trade theory, namely (1) the problems of market imperfection; (2) the strategic industrial behaviour of businesses and governments under imperfect competition (new industrial economic theory); (3) the new theory of economic growth; (4) the arguments of political economy.

In addition to monopolistic and oligopolistic competition and their derivatives, market imperfection is reinforced by the phenomenon of information asymmetry. For understanding the strategic industrial behaviour of businesses and national governments, we can use the game theory, the inter-temporal optimization for temporal conjunction between state economic policy and economic processes or business activities.

The working paper by Ionaşcu and Žigić (2001) belongs to most well-grounded and accurate studies of information asymmetry in the context of strategic industrial and trade policy used by governments and firms under imperfect competition. On the basis of fundamental research works (Brander and Spencer (1985), Brander (1995), Neary and Leahy (1997)), Ionaşcu and Žigić examine the choice of strategic R\&D investment behaviour of a firm that operates under Cournot competitive conditions (production volume approach) or Bertrand competitive conditions (price approach) for the case of absolute Nashequilibrium. At that, it is assumed that R\&D-investment can increase the firm's 
production efficiency by reducing its production costs and improve its terms of trade on the foreign markets. At the same time, the research takes into account the problem of information asymmetry between the country's government which pursues certain industrial and trade policy to benefit from international trade and achieve the desired social and economic effect by encouraging private sector R\&D-investment - and a particular firm, which, on its part, intends to profit from competition without consideration for other firms' market results and the country's overall socio-economic effect. The country's government is assumed to assist private $R \& D$ investment through industrial and export grants, thus carrying out an interventionist industrial and trade policy. The firm with higher R\&D-investment efficiency functioning under conditions of Cournot competition would press towards the R\&D-investment quota higher than socially-optimal level in order to accumulate more financial resources in the form of governmental industrial and export grants. From the socio-economic perspective, the above-optimal level of R\&D-investment would lead to inefficient resource allocation in the country, thus inducing the government to resort to non-interventionist economic policy and ensure free trade in order to restore the economic equilibrium of the real sector. Alternatively, if a firm operates under conditions of Bertrand competition and has higher R\&D-investment efficiency than its rivals, it can increase its R\&Dinvestment to push them out of the market on the basis of price competition and consequently aggravate the social and economic situation in the country. In order to prevent price discrimination, the government would shift from noninterventionist to pro-active interventionist economic policy and impose a tax on R\&D-intensive production volumes, expecting that the firm would reduce its production in response. Under conditions of information asymmetry, when, for example, the government lacks information about the type of competition on the market and cannot predict the reaction of a particular firm to announced industrial and trade policy, there is a risk of insufficient or excessive R\&Dinvestment in the country's economy and crowding less efficient firms out of the market in the process of competition. This can negatively influence the social and economic development of the country. A firm is able to play a trick on the government and imitate the competition of a type other than existing in reality. Depending on the situation, the firm can achieve the desired effect -either to get production grants, thus forcing the government to carry out interventionist economic policy, or evade tax on production volumes by behaving so that it would lead to state non-interventionist industrial and trade policy. The problem of market imperfection driven by information asymmetry can become especially acute due to non-cooperative behaviour of the firms and the government in the process of differentiated production and trade in differentiated goods.

The crucial factor in forming the strategic industrial behaviour in the modern global economy is the allocation of industrial production in space. In this context, in the second half of 1980s originated the New Economic Geography Theory within the scope of the New Trade Theory. New Economic Geography 
is a science about allocation of economic activity in space. Traditional neoclassical models of international trade do not take into account economic globalization and regionalization. They assume that production factors are immobile internationally. New Economic Geography aims to explain how the economic globalization followed by economic liberalization and regional economic integration can lead to concentration of economic activity in certain geographic areas (regions), while other geographic areas (regions) reduce to de-industrialized ones because firms and labour force desert their production locations. In other words, industrial production can concentrate in a certain region or nearby. Owing to industrial agglomeration, the shaping of a "regional core" occurs, whereas other regions constitute an underdeveloped geographical "periphery". The periphery is characterized to some extent by the development of agriculture, mining, natural resources, primary processing industries, and transport (transit) services. Regions of periphery can turn into "transit deserts", i.e. they lose their significance as production locations, begin to specialize in producing transit services and act as geographical intermediaries between the areas with high economic activity.

Industrial production and international trade in differentiated goods tend to concentrate in locations where large markets exist, and large markets are where industrial production concentrates. Myrdal (1957) defined this process as "circular causation". It becomes more advantageous to set production near the core because it is cheaper to purchase intermediate and final goods there. This motivates the linkages between the firms and the suppliers of intermediate goods ("backward linkages"). At the same time, the core provides a higher living standard, a higher level of labour concentration and hence a higher level of purchasing power. The availability of a large consumer market strengthens linkages between the firms and the consumers of final goods ("forward linkages"). These linkages were extensively described by Hirschman in as early as 1958 and used by Krugman (1991), Krugman and Venables (1993), Ricci (1996), and Midelfart-Knarvik et al. (2000) to characterize new trends in the development of international specialization in the context of strategic industrial behaviour of economic agents.

The majority of the New Trade Theory models containing elements of New Economic Geography assume the availability of industries that produce differentiated goods under conditions of monopolistic competition, increasing returns to scale, and trade (transport) costs. Some New Economic Geography models raise the question of comparative advantage within the same differentiated industry in the core from the perspective of differences in technology and qualitative differences in capital intensity. Therefore, one can speak of incomplete specialization in the core. It seems doubtful that traditional Heckscher-Ohlin (Helpman and Krugman, 1985) and neo-ricardian (Ricci, 1996 and 1997) theories have entirely lost their significance in explaining international trade in advanced industrial countries.

The intensity of international trade and degree of international specialization of countries or regions (i.e. complete or incomplete specialization) are explained 
by centripetal and centrifugal forces. Geographic proximity of the countries, developed transport, telecommunication networks and social infrastructure, as well as institutional framework, similarities in cultures and languages of the countries, and higher wage level belong primarily to centripetal forces. Centrifugal forces are represented by increasing geographical distance between countries, high trade costs, congestion costs (Helpman, 1998), market entry and exit restrictions, and high criminality.

Gravity modelling (Helpman and Krugman (1985), Bergstrand (1989)) serves as a methodological base for empirical evaluation of both traditional neoclassical and New Trade Theory factor influence on bilateral trade flows between countries. The gravity factors that can explain international trade within the scope of New Trade Theory include geographical distance between trading countries as a proxy for transport costs, trade costs (cumulative average customs tariff or aggregate index of economic freedom "trade policy" as a dummy variable), intra-industry trade indexes (Evenett and Keller, 1998), FDI as a proxy for multinational activities, GDP per capita and Gini income distribution coefficient for characteristics of economic size and demand for differentiated goods, as well as Gini coefficient for measuring the degree of industrial production concentration (Klüver and Rübel, 1998).

Evenett and Keller (1998) were first to prove empirically that the model with increasing returns to scale can explain excellently the use of gravity equations in the international trade theory. Feenstra et al. (2001) extended this analysis using Rauch's classification of tradable goods (Rauch, 1999). They argue that international trade models with monopolistic competition ensure success in using gravity equations when considered are not the flows of total tradable goods, but only the flows of differentiated tradable goods taken as a separate category. Based on the gravity modelling, Carrillo and Li (1995) consider the influence of preferential (regional) trade agreements on trade flows of differentiated and homogenous goods, in particular homogenous goods with reciprocal dumping. The connection between gravity modelling and international trade containing elements of New Economic Geography was presented by Redding and Venables (2000), Eaton and Kortum (2002).

New Trade Theory is closely integrated with New Growth Theory. Externalities, which are considered to result from technology and knowledge spillovers, become a source for endogenous economic growth of many countries in the process of international trade. Grossman and Helpman (1991) show in their model how international trade -- through technological knowledge spillovers -- contributes to the development of R\&D industries as drivers of economic growth in the modern global economy. International technology transfer leads to increased competition, entrepreneurship initiative and enlarged size of the market on which innovative firms operate.

Other models based on international technology transfer emphasize the positive impact of economic openness on the acceleration of economic growth, focusing on the role of capital-intensive imports (Coe et al. (1995), Lee (1992)). Inasmuch as the information about new technology is embedded in 
capital-intensive goods, the externalities from international technology transfer are directly proportional to capital-intensive imports.

When considering the new growth theory, many researchers with neoclassical convictions argue that international trade liberalization contributes to economic growth of a country (mostly in view of externalities from knowledge and new technology transfer), whereas some researchers think that economic openness and free trade can hinder economic growth. They reconsider the arguments for state protection of infant industries in low-industrialized countries. The experience of many poor countries shows that free trade and economic liberalization deepened the specialization based on low-technology products, while international trade barriers and state interventionist economic policy favoured the formation of a powerful industrial economic system and international specialization of a higher level in some developing countries.

\section{Ukrainian Economy within the Scope of New Trade Theory}

In our previous studies we determined that Ukraine's international trade specialization is mainly inter-industry in nature (Konchyn, 2005). Table 5 presents the highest levels of intra-industry trade of Ukraine with its main trade partners in 2005.

From calculated intra-industry (IIT) indexes, we can see that, in terms of its foreign trade turnover, Ukraine reveals its highest levels of IIT with Russia (GL index $=0.231$ or IIT share of $23.12 \%$; main IIT commodity groups with regard to trade volumes and value of G-L index include: iron ore and concentrates; steel flat-rolled metal; rubber pneumatic tyres; automatic analyzing and controlling instruments and apparatus; ball/roller bearings; taps/cocks/valves, fittings for tubes and pipes; insulated wires and cables; transmission shafts and cranks; engines and generators, electric; ferroalloys), Rumania (G-L index $=0.256$ or IIT share of $25.56 \%$ thanks to petroleum oils and oils from bituminous minerals other than crude), Hungary (G-L index = 0.189 or IIT share of $18.93 \%$; main IIT commodity groups include: parts accessories for radio- and video equipment; polymers of ethylene, in primary forms; stainless steel bars and rods; cyclic carbohydrates; monocarbon acyclic acids; ethyl alcohol; electric transformers; electric engines and generators; parts and accessories for motor vehicles; petroleum oils and oils from bituminous minerals other than crude), Belarus (G-L $=0.160$ or IIT share of 16.01\%; main IIT commodity groups include: parts and accessories for motor vehicles; corded coverings for tyres; ball/roller bearings; woven fabrics; steel bars and rods; insulated wires and cables), Belgium (G-L index $=0.126$ or IIT share of $12.57 \%$; main IIT commodity groups include: processed and unprocessed diamonds; joinery; colouring matters), Poland (G-L index $=0.101$ or IIT share of $10.14 \%$; main IIT commodity groups include: alloy steel bars and rods; polymers of ethylene, in primary forms; metal structures of aluminium; petroleum oils and oils from bituminous minerals other than crude; flat-rolled metals of steel and stainless steel; sugar). 
Table 5. Ukraine's Highest Levels of Intra-Industry Trade (IIT) with Its Main

Trade Partners, 2005

\begin{tabular}{|c|c|c|c|c|c|c|}
\hline \multirow[t]{2}{*}{$\begin{array}{l}\text { Position, } \\
\text { ranked by } \\
\text { foreign } \\
\text { trade } \\
\text { turnover }\end{array}$} & \multirow[t]{2}{*}{ Country } & \multirow[t]{2}{*}{$\begin{array}{l}\text { Number of traded } \\
\text { commodity } \\
\text { groups, } \\
\text { out of } 1182 \\
\text { groups }(2005)\end{array}$} & \multirow{2}{*}{$\begin{array}{l}\text { Volume of } \\
\text { intra- } \\
\text { industry } \\
\text { trade } \\
(2005) \text {, } \\
\text { thou.USD }\end{array}$} & $\begin{array}{l}\text { Grubel- } \\
\text { Lloyd } \\
\text { Index } \\
(2005)\end{array}$ & $\begin{array}{l}\text { Modified } \\
\text { Michaeli } \\
\text { Index } \\
(2005)\end{array}$ & $\begin{array}{l}\text { Grubel- } \\
\text { Lloyd } \\
\text { Index } \\
(2003)\end{array}$ \\
\hline & & & & \multicolumn{3}{|c|}{$\begin{array}{l}\text { Intra-industry trade, } \% \text { of total } \\
\text { trade }\end{array}$} \\
\hline 23 & Rumania & 551 & 175413.80 & 25.56 & 26.73 & $8.81 *$ \\
\hline 1 & Russia & 1043 & 4684775.00 & 23.12 & 21.64 & 16.45 \\
\hline 10 & Hungary & 728 & 251802.47 & 18.93 & 18.79 & 11.03 \\
\hline 8 & Belarus & 788 & 293099.45 & $16.01 \downarrow$ & 15.95 & 16.11 \\
\hline 31 & Belgium & 706 & 64056.24 & 12.57 & 11.53 & 3.90 \\
\hline 19 & Slovak Rep. & 596 & 89865.94 & 11.10 & 12.26 & 6.57 \\
\hline 34 & Lithuania & 635 & 43970.33 & 10.75 & 10.70 & 6.01 \\
\hline 7 & Poland & 922 & 243230.18 & 10.14 & 10.55 & 8.33 \\
\hline 45 & Denmark & 581 & 25623.58 & 9.08 & 9.09 & 2.63 \\
\hline 2 & Germany & 1042 & 404433.41 & $8.70 \downarrow$ & 10.29 & 10.22 \\
\hline 22 & Moldova & 831 & 63624.88 & 8.34 & 12.00 & $\mathrm{n}$ \\
\hline 21 & Austria & 689 & 61811.52 & $8.10 \downarrow$ & 7.67 & 22.07 \\
\hline 9 & USA & 888 & 123827.70 & $7.52 \downarrow$ & 7.91 & $8.05 *$ \\
\hline 16 & Kazakhstan & 555 & 54422.56 & 6.42 & 5.17 & 3.49 \\
\hline 3 & Italy & 914 & 180640.05 & $6.18 \downarrow$ & 7.18 & 7.59 \\
\hline 13 & Netherlands & 813 & 58588.77 & 6.00 & 6.19 & 2.90 \\
\hline 37 & Latvia & 547 & 21028.87 & 5.61 & 9.21 & 4.42 \\
\hline 14 & Czech Rep. & 755 & 50207.13 & 5.17 & 5.20 & 4.16 \\
\hline 15 & UK & 792 & 43392.36 & $5.09 \downarrow$ & 5.08 & 25.12 \\
\hline 25 & Bulgaria & 562 & 31918.10 & $5.00 \downarrow$ & 7.43 & $11.79 *$ \\
\hline 12 & France & 826 & 41277.39 & $4.15 \downarrow$ & 4.25 & 5.17 \\
\hline 6 & China & 864 & 85306.23 & 3.38 & 4.23 & $\mathrm{n}$ \\
\hline 5 & Turkey & 787 & 65687.46 & 2.53 & 3.73 & $\mathrm{n}$ \\
\hline
\end{tabular}

Notes: * data for $2002 ; \mathrm{n}-$ no data

Source: author's calculations based on the data on foreign trade in goods according to 4-digit classification of TN ZED (HS Rev. 3) International Trade Classification of Ukraine's State Statistics Committee.

Worth noting is the fact that recently Ukraine has exhibited a tendency to deepening IIT, especially owing to intensified cooperation with CEEC and Russia. The major objects of intra-industry trade of Ukraine are not the final goods, as it is in advanced industrial countries, but the intermediate goods of industrial purpose. A part of intra-industry trade flows can be considered horizontal and described by monopolistic competition and differentiated demand. The other part of IIT represents vertical intra-industry trade, i.e. when 
international trade involves goods of different production stages within the same commodity group ("intermediate vs. final goods problem"). Vertical IIT expressed by export-import overlap can be explained by means of various forms and mechanisms of international business cooperation set up by foreign firms or MNCs. For example, we can speak of the re-export strategy, i.e. establishing the production on the basis of delivered materials, parts and accessories in the recipient country endowed with low labour costs and available facilities. More often than not the products are made to order and reexported by companies to meet the needs of their country of origin or a third country. ${ }^{2}$ Another form of business cooperation is when a foreign (multinational) company sets up the production of intermediate goods in the recipient country, shipping them later to its country of origin or a third country for subsequent processing or assembling. After that, the company delivers final goods within the same commodity group back to the recipient country.

On the one hand, vertical intra-industry trade in Ukraine can be explained within the scope of Traditional Trade Theory because it reflects differences in relative factor endowments (factor intensity of production) or technology between Ukraine and its trade partners. On the other hand, IIT can be the subject of New Trade Theory because of its dependence on the activity and behaviour strategies of foreign firms and MNCs on the Ukrainian market.

The New Trade Theory has limited scope for explanation of actual economic processes in Ukraine in view of the following circumstances.

1. The postulates of the New Trade Theory reveal themselves when trading partner-countries have similar, high economic development levels (similarly high GDP/GNI per capita). Only subject to this condition can there be high propensity to satisfy the differentiated demand and hence develop the differentiated industrial production. The value of this indicator for Ukraine leaves it behind the EU- and EFTA countries, as well as the USA, which are its main trade partners and its primary source of imported differentiated industrial goods.

Therefore, the economic processes and effects within the scope of New Trade Theory will become more apparent in the course of Ukraine's income

\footnotetext{
${ }^{2}$ As an example we present the HS Rev.3 commodity group 8518 "Microphones and props for them; loudspeakers, integrated and not integrated; headphones and combined microphone/loudspeaker sets; electric audio amplifiers; electric loudspeaker equipment", which is a significant article of trade between Ukraine and Austria in terms of trade volume (the $5^{\text {th }}$ largest export and $2^{\text {nd }}$ largest import commodity group in the trade structure) and level of intra-industry trade $(98.88 \%$ in $2002,95.48 \%$ in 2003 , and $80.5 \%$ in 2004). Within this commodity group, in 2004 Ukraine imported from Austria 98.9\% of parts and accessories for loudspeakers (subgroup 85189) and exported to Austria more than $96.7 \%$ of loudspeakers as a product of high processing degree (subgroup 85182). Using Kandogan's methodology (Kandogan, 2003), we determined that the share of horizontal IIT in the total IIT of Ukraine with Austria within the commodity group 8518 made only $4.1 \%$. This share can be fully explained by the New Trade Theory postulates. The rest of the total IIT $(95.9 \%)$ should be considered as vertical IIT and can be investigated within the scope of either Traditional or New Trade Theory.
} 
convergence (with consideration for PPP problem) with advanced industrial countries, in particular with the EU-countries, which seems possible in the long term if Ukraine persists in deepening its entry into the system of international division of labour, liberalizing its domestic market, foreign trade and international capital flows with simultaneous integration into the European economic area.

2. The difference between Ukraine's production and trade structure and the production and trade structures of its trade partners explains the nonhomogeneity of consumer preferences. According to New Trade Theory, a country's integration with a certain regional economic block can lead to increasing convergence of trade structures and, thus, to development of intraindustry trade of a higher level between the countries that integrate. This argument calls for complex empirical research of Ukraine's economic integration with its trade partners in both the European Union and the Single Economic Area (i.e. with Russia, Belarus and Kazakhstan).

Nevertheless, it is believed that international specialization of Ukraine would develop optimally under deepening of its industrial and trade relations with advanced industrial countries, which have objectively reached the highest level of international specialization and product differentiation. In view of the optimization of their reciprocal demand, advanced industrial countries would try to pull the Ukrainian economy towards European economic area in order to realize their trade and investment interests.

We suggest cluster analysis for measuring the homogeneity of Ukraine's trade structure and the trade structures of its trade partners within the regional EU and SEA integration blocks. We use 4-digit marks for commodity groups according to HS Rev.3 Trade Classification and analyze main export and import commodity groups of Ukraine and the EU and SEA countries within their world trade in 2003.

The analysis shows that in the general sample of the EU and SEA countries stands out a representative cluster of the "industrial capital-intensive core" of the EU, with highly homogenous trade structures of Germany, Hungary, Slovak Republic, Austria, Czech Republic, United Kingdom, Sweden, and Slovenia (See Figure 1). Italy and France, which have similar trade structures, draw near the core cluster. Luxembourg and Kazakhstan also stand close to this cluster, owing rather to their capital- and R\&D-intensive type of import structures. Luxembourg and Kazakhstan have similar export structures of resources-intensive type (metals and metal products).

We can also distinguish a separate cluster represented by Portugal, Lithuania, Latvia, and Poland followed by a less homogeneous Belarus. This cluster represents a so-called "European periphery" which reflects international trade in mostly resources- and labour-intensive goods. Within this cluster, Portugal and Poland are characterized by MNCs' well-established vertical production in motor vehicle and electric industries.

Still another cluster of European periphery is represented by trade structures of Denmark, Ukraine and Greece. The export structures of Ukraine and Denmark 
are homogeneous due to a relatively high share of resources-intensive (in particular petroleum) products and foodstuffs (See Figure 2). It should be noted that Denmark reveals a considerably high heterogeneity of its production and trade structure in relation to production and trade structures of the countries which form the European capital-intensive core. Denmark also has leading trade positions in science-intensive products in addition to its high share of resources-intensive products.

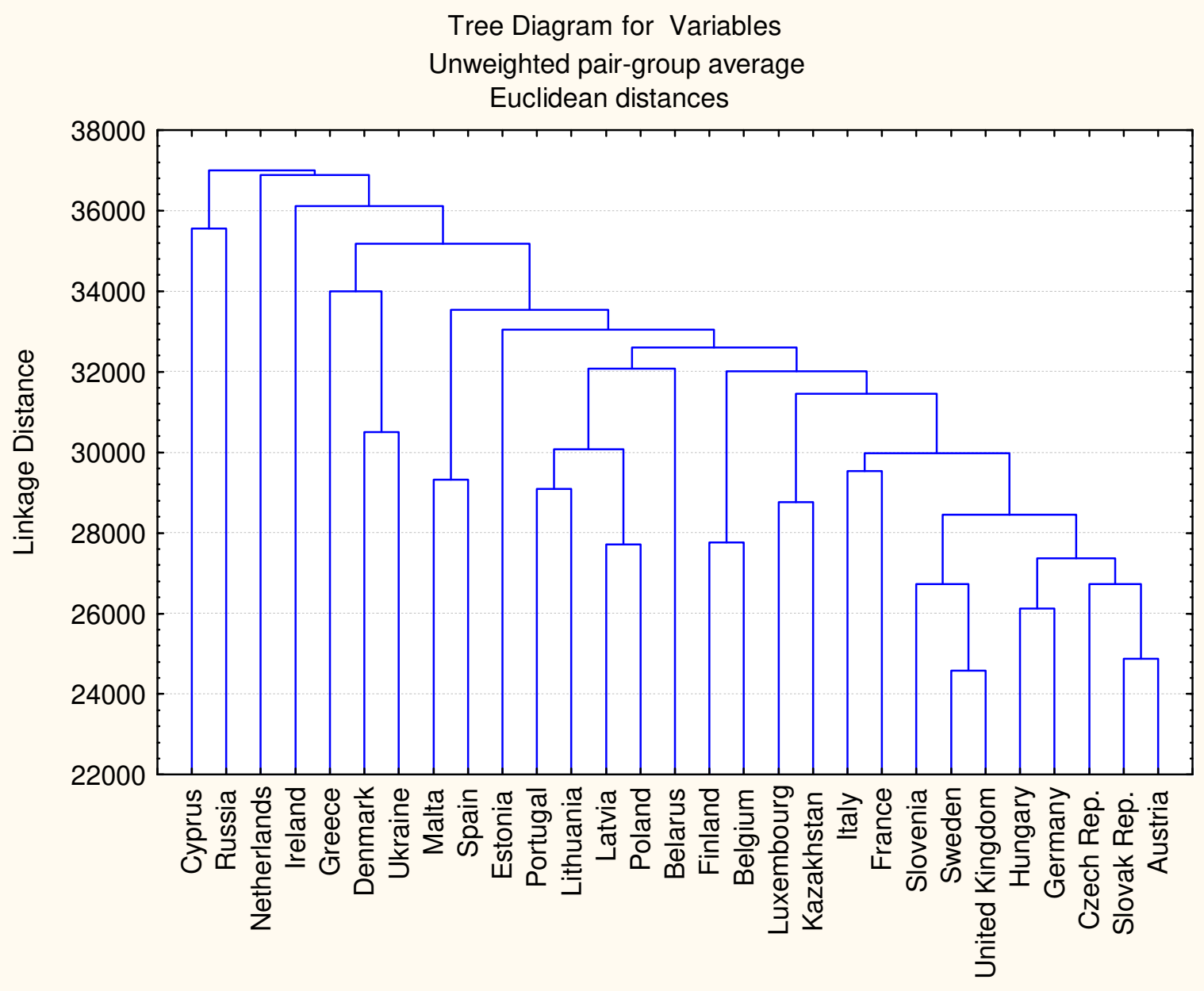

Figure 1. Country Clusters According to Homogeneity of Trade Structures.

Being in the same cluster of import structures with Greece, Lithuania and to some extent with Poland, Latvia and Belarus, Ukraine shows a tendency to effective importing, which contributes to structural changes directed at meeting the needs of the European economic area (See Figure 3). The participation of Ukraine and Greece in vertical labour-intensive production in the light industry with the EU-countries is also a significant factor of the homogeneity of their import structures. 


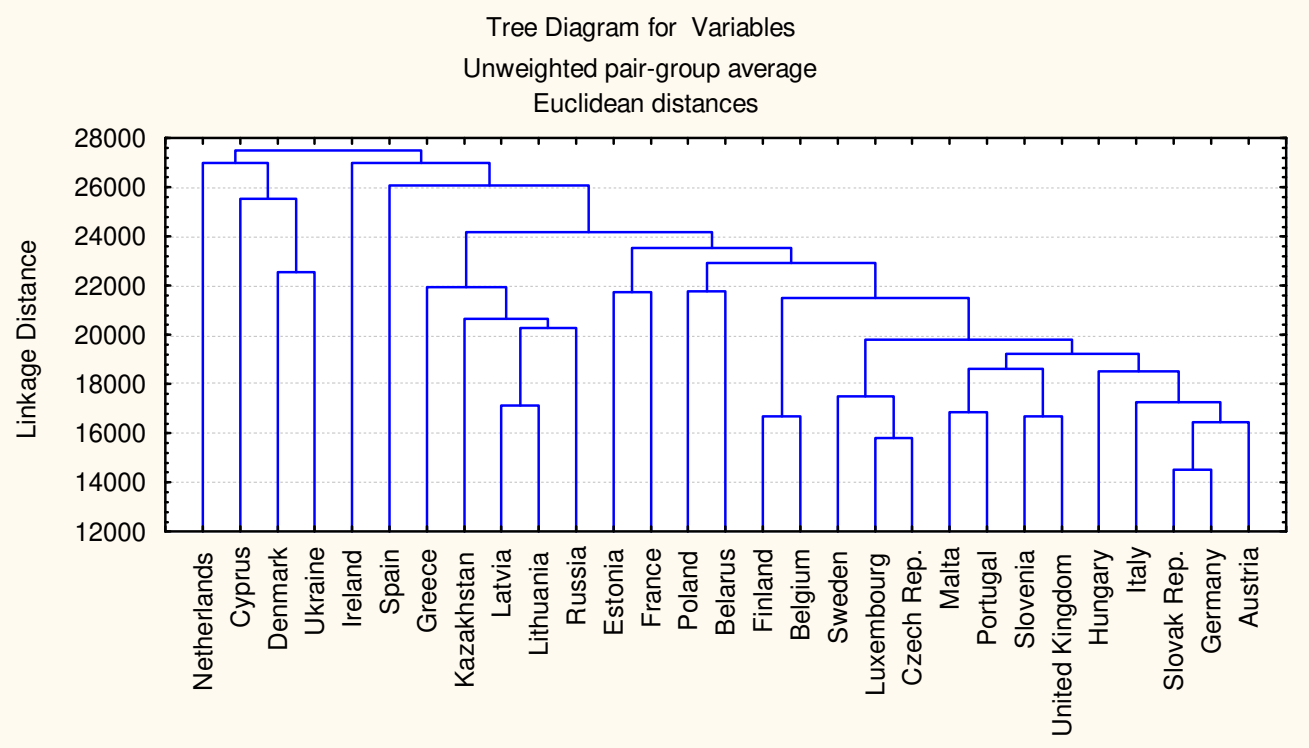

Figure 2. Clusters according to Homogeneity of Export Structures.

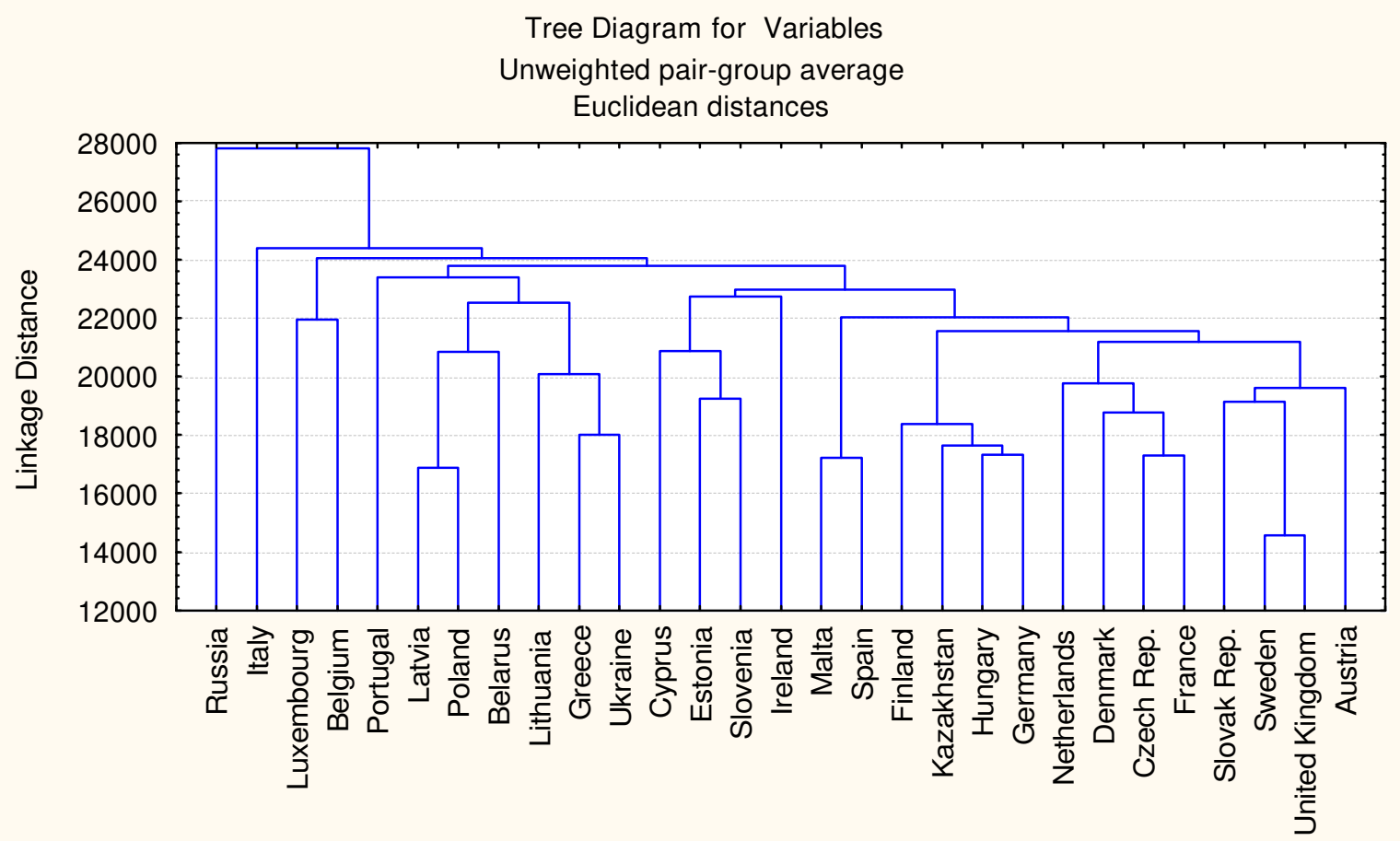

Figure 3. Clusters according to Homogeneity of Import Structures.

Ukraine's main problem in revealing its trade homogeneity in relation to trade structures of its trade partners in the EU and SEA is its export commodity structure. Ukraine's export structure is heterogeneous in comparison to the 
majority of the EU and SEA countries, with basic metals, fabricated metal products, agricultural goods, and foodstuffs traditionally prevailing in it. Moreover, Ukraine's export specialization, which reflects its industrial specialization, is highly diversified. In view of this, in the future, if Ukraine integrates with one or another regional economic block, the achievement of real convergence will be a painful process involving decision-making problems with regard to its further participation in the monetary union.

We should also mention the countries that have heterogeneous trade structures compared to majority of the sampled countries. This primarily concerns the export structures of the Netherlands (prevalence of agricultural products, foodstuffs and science-intensive goods), Ireland (prevalence of computer technologies, agricultural products and foodstuffs) and Cyprus (agricultural products and labour-intensive goods). Russia exhibits high level of heterogeneity because of its substantial exports of resources and absolutely different structure of imports that does not fit into the system of consumer preferences of the Euro-integration area (See Figure 3). Russia's import structure consists of a large number of agricultural and mass consumption goods, which testifies to the fact that the domestic producer in Russia does not fully satisfy even the basic consumer demand. Russia's imports of differentiated goods of industrial purpose are represented even worse than in Kazakhstan, Belarus and Ukraine.

Table 6 shows that under conditions of actual trade specialization and adherence to market principles, Ukraine's reciprocal demand-based foreign trade with the EU countries can be more beneficial than trade within the Single Economic Area.

Taking into account the relative heterogeneity of Ukraine's export structure in relation to Russia's and Kazakhstan's import structures (which is shown by relatively large Euclidean distances), one can assert that Ukraine's export potential on the markets of Russia and Kazakhstan is not as high as it is considered to be. The same is true for export potentials of Belarus and Kazakhstan, as well as Russia (in differentiated industrial goods), on the Ukrainian market. This argument casts doubt on the possibility of a more intensive development of Ukraine's intra-industry trade in differentiated goods with the SEA countries in the course of deepening Eurasian economic integration than this would be the case in the course of European economic integration.

If the similarities in the levels of economic development of Ukraine, Russia, Belarus and Kazakhstan -- which clearly outweigh similarities in economic development of Ukraine and EU countries -- were taken as a basis for establishment of a customs union within the Single Economic Area, the equalization of relative factor endowments and relative factor prices between Ukraine and the SEA-countries would occur at a much faster pace than it would be the case under the system of European common customs tariff. Price equalization is a good foundation for development of economic processes 
within the scope of the New Trade Theory. However, inasmuch as consumer preferences in Ukraine differ from those of its two SEA-partners (Russia and Kazakhstan), their disposition to intensify intra-regional trade relations with Ukraine in the future would be reduced. The SEA countries would rather prefer to expand their integrated export potential (for example, by forming big oligopolistic financial and industrial groups in the mining, metallurgy, heavy engineering, aircraft and space industries on the basis of intra-regional mergers and acquisitions, thus enjoying external economies of scale) and satisfy their individual importing wishes on the markets of third countries in compliance with the postulates of the Traditional Trade Theory.

Table 6. Countries Ranked by Homogeneity of Ukraine's Potential Reciprocal Demand, 2003.

\begin{tabular}{|c|c|c|c|c|c|}
\hline Rank & $\begin{array}{l}\text { Ukraine's import } \\
\text { structure to export } \\
\text { structure of its trade } \\
\text { partner }\end{array}$ & $\begin{array}{l}\text { Euclidean } \\
\text { distance }\end{array}$ & Rank & $\begin{array}{l}\text { Ukraine's export } \\
\text { structure to import } \\
\text { structure of its trade } \\
\text { partner }\end{array}$ & $\begin{array}{l}\text { Euclidean } \\
\text { distance }\end{array}$ \\
\hline 1 & Germany & 20058.47 & 1 & Italy & 21717.73 \\
\hline 2 & Italy & 20656.99 & 2 & Cyprus & 22263.93 \\
\hline 3 & Finland & 20862.81 & 3 & Belarus & 23122.89 \\
\hline 4 & Slovak Republic & 21881.52 & 4 & Belgium & 23202.44 \\
\hline 5 & Slovenia & 22689.53 & 5 & Slovenia & 23372.61 \\
\hline 6 & Malta & 22792.59 & 6 & Greece & 23676.15 \\
\hline 7 & Estonia & 22890.87 & 7 & Portugal & 24114.47 \\
\hline 8 & Austria & 23268.88 & 8 & France & 24869.11 \\
\hline 9 & Sweden & 23392.34 & 9 & Lithuania & 25060.00 \\
\hline 10 & Latvia & 23687.73 & 10 & Latvia & 25214.63 \\
\hline 11 & Russia & 23862.29 & 11 & Poland & 25277.37 \\
\hline 12 & Czech Republic & 24181.48 & 12 & Spain & 25294.67 \\
\hline 13 & Poland & 24377.02 & 13 & Austria & 25439.25 \\
\hline 14 & Luxembourg & 24379.41 & 14 & Slovak Republic & 25877.06 \\
\hline 15 & Hungary & 24742.98 & 15 & United Kingdom & 26102.73 \\
\hline 16 & Greece & 24854.42 & 16 & Luxembourg & 26299.84 \\
\hline 17 & Spain & 25063.82 & 17 & Malta & 26372.02 \\
\hline 18 & Portugal & 25079.77 & 18 & Czech Republic & 26727.50 \\
\hline 19 & France & 25510.37 & 19 & Denmark & 27122.57 \\
\hline 20 & Ireland & 25612.00 & 20 & Estonia & 27128.80 \\
\hline 21 & Belgium & 25729.13 & 21 & Kazakhstan & 27511.07 \\
\hline 22 & United Kingdom & 25763.71 & 22 & Netherlands & 27563.61 \\
\hline 23 & Kazakhstan & 25835.02 & 23 & Sweden & 27575.12 \\
\hline 24 & Denmark & 25840.15 & 24 & Germany & 27949.59 \\
\hline 25 & Belarus & 25853.91 & 25 & Finland & 28016.37 \\
\hline 26 & Cyprus & 26964.20 & 26 & Ireland & 28460.40 \\
\hline
\end{tabular}




\begin{tabular}{|l|l|l|l|l|l|}
\hline 27 & Lithuania & 27388.91 & 27 & Hungary & 29840.57 \\
\hline 28 & Netherlands & 29752.49 & 28 & Russia & 29858.18 \\
\hline
\end{tabular}

Source: author's calculations based on international trade data of Ukrainian State Statistics Committee and UN Comtrade.

Hence, for the SEA, the New Trade Theory would be able to explain the effect of external increasing returns to scale and the horizontal export strategy of new-established intra-regional transnational companies towards third countries. These TNCs would join the system of intense competition on the world market. However, such an integration block would form no preconditions for Ukraine to intensively develop its intraregional intra-industry trade since the convergence of reciprocal demand structures in the SEA could linger out because of the growing volumes of inter-industry trade with the third countries.

The postulates of the New Trade Theory could be applied to the cooperation of Ukraine and the EU in the medium-term perspective to explain the Ukrainian economy's take-over by western MNCs, saturation of a relatively large Ukrainian consumer market with differentiated goods under conditions of monopolistic and oligopolistic competition, internationalization of technology transfer, and development of vertical intra-industry trade.

3. The question of whether the models of New Trade Theory based on assumptions of monopolistic and oligopolistic competition can describe economic processes and effects, as well as the choice of business and governmental strategic behaviour, for developing and transition countries is debatable (Lucas 1988; Bardhan 1995; Ruttan 1998). At the time when oligopolistic or monopolistic MNCs as global market players use various types of strategic behaviour in the developed industrial countries, in the developing countries - characterized by low income levels and, therefore, insufficient differentiated demand, and sometimes high protectionism - the strategic behaviour of companies is quite limited.

As the experience of European transition countries shows, the opening-up of their economic systems for international competition and FDIs, deepening economic liberalization and integration, and on this basis, the realization of real convergence within the integration block lead to the increased role of New Trade Theory in explaining their international economic relations. The larger the part of a transition country's economy is taken over by western MNCs, the more its markets are defined by monopolistic competition. It should be noted that for open developing and transition countries, the questions of strategic business behaviour are considered in the context of sales, industrial and investment expansion of foreign MNCs, rather than in view of the companies' objective need to amalgamate their industrial and economic activity in order to realize internal economies of scale or economies of scope. The strategic behaviour directed at using economies of scale or economies of scope to rationalize the company's production and ensure its survival or higher profits on the markets with already satisfied differentiated demand is typical of advanced industrial countries. 
The range of strategies used by MNCs on the Ukrainian market, especially in their interaction with the Ukrainian government, is very limited due to the 2005 practice of imposing informal limitations on access of foreign MNCs to the socalled national "strategic enterprises" and "priority industries". When in many transition CEE-countries western MNCs took over inefficient but potentially promising enterprise assets, the newly-formed Ukrainian business elite used state authorities to preserve control over national economy.

This notwithstanding, in the 1990s, the first big Ukrainian-Korean joint venture AutoZaZ-Daewoo was set up in the motor vehicle industry with foreign capital vested by the Korean TNC Daewoo. In 2001 started the expansion of Russian capital on the Ukrainian market, mainly in the form of cross-border acquisitions of enterprise assets, in particular aluminous and aluminium enterprises. However, the value of these acquisitions was not high. After the Orange Revolution in Ukraine, the German MNC Metal Stil with assistance of Ukrainian democratic political elite took over (privatized) big metallurgical state enterprise Kryvorizhstal in 2005. Later, an Austrian financial MNC Raiffeisen Bank purchased the assets of the Ukrainian Aval bank.

In comparing cross-border M\&As, we can see that Ukraine practically has not been taking part in these processes since its independence (see Table 7). In this regard, the New Trade Theory postulates about strategic behaviour, monopolistic competition, differentiated goods, New Economic Geography, and international technology transfer will develop in Ukraine only when it first fulfils the Traditional Trade Theory thesis - the non-discriminative access of foreign companies (multinational corporations) to domestic market of the recipient country, i.e. guaranteeing the principle of functional market competition and favourable conditions for acquisition of assets of domestic enterprises.

Table 7. Consolidation of Capital through Cross-Border Mergers \& Acquisitions

\begin{tabular}{|c|c|c|c|c|c|}
\hline \multirow{2}{*}{ Region/Country } & \multicolumn{2}{|c|}{$\begin{array}{l}\text { Cross-Border Sales of } \\
\text { Corporate Assets as a } \\
\text { Result of M\&As, } \\
\text { millions USD }\end{array}$} & \multirow[t]{2}{*}{ Region/Country } & \multicolumn{2}{|c|}{$\begin{array}{l}\text { Cross-Border Purchases } \\
\text { of Corporate Assets as a } \\
\text { Result of M\&As, } \\
\text { millions USD }\end{array}$} \\
\hline & 1988-1996 & $1997-2004$ & & 1988-1996 & $1997-2004$ \\
\hline \multicolumn{6}{|c|}{$\begin{array}{l}\text { Europe and CIS } \\
\end{array}$} \\
\hline $\begin{array}{l}\text { United } \\
\text { Kingdom }\end{array}$ & 185586 & 654370 & United Kingdom & 221358 & 1035245 \\
\hline Germany & 46922 & 473720 & France & 104684 & 426250 \\
\hline France & 72207 & 175661 & Germany & 71936 & 364522 \\
\hline Netherlands & 34196 & 172243 & Netherlands & 51337 & 207834 \\
\hline Sweden & 32637 & 115833 & Switzerland & 56786 & 154632 \\
\hline Italy & 33329 & 84880 & Spain & 18542 & 143523 \\
\hline Spain & 24491 & 67732 & Sweden & 35547 & 84980 \\
\hline
\end{tabular}




\begin{tabular}{|c|c|c|c|c|c|}
\hline Belgium & 20780 & 62985 & Italy & 23385 & 78335 \\
\hline Switzerland & 19328 & 57446 & Belgium & 13085 & 68869 \\
\hline Norway & 7591 & 35582 & Finland & 5313 & 47797 \\
\hline Finland & 4898 & 31040 & Denmark & 3256 & 26588 \\
\hline Denmark & 3128 & 29857 & Ireland & 8535 & 26141 \\
\hline Ireland & 4904 & 27451 & Norway & 9114 & 22856 \\
\hline Poland & 4004 & 24321 & Luxembourg & 5139 & 20142 \\
\hline Luxembourg & 2038 & 21760 & Austria & 880 & 15142 \\
\hline Austria & 3247 & 19879 & Portugal & 1297 & 14586 \\
\hline Russia & 659 & 18999 & Russia & 511 & 11269 \\
\hline Czech Republic & 4764 & 14845 & Greece & 288 & 9532 \\
\hline Portugal & 3210 & 8210 & Hungary & 64 & 3406 \\
\hline $\begin{array}{l}\text { Slovak } \\
\text { Republic }\end{array}$ & 246 & 7118 & Cyprus & 41 & 2042 \\
\hline Hungary & 5130 & 6774 & Poland & 64 & 1887 \\
\hline Rumania & 504 & 5541 & Czech Republic & 304 & 1521 \\
\hline Bulgaria & 213 & 5490 & Bulgaria & 3 & 903 \\
\hline Greece & 1230 & 4873 & Slovak Republic & 45 & 776 \\
\hline Croatia & 253 & 3602 & Kazakhstan & 450 & 181 \\
\hline Kazakhstan & 3666 & 3356 & Slovenia & 0 & 165 \\
\hline Slovenia & 89 & 2199 & Ukraine & 0 & 157 \\
\hline Azerbaijan & 1 & 1475 & Croatia & 0 & 80 \\
\hline Ukraine & 96 & 713 & Rumania & 0 & 30 \\
\hline Cyprus & 0 & 62 & Azerbaijan & 0 & 0 \\
\hline Belarus & 0 & 7 & Belarus & 0 & 0 \\
\hline \multicolumn{6}{|c|}{ North America } \\
\hline USA & 417501 & 1277261 & USA & 290322 & 864754 \\
\hline Canada & 60174 & 208998 & Canada & 63255 & 214733 \\
\hline Mexico & 9670 & 47464 & Mexico & 5970 & 22556 \\
\hline \multicolumn{6}{|c|}{ Asia } \\
\hline Australia & 53292 & 115599 & Australia & 39752 & 107232 \\
\hline Japan & 5300 & 79772 & Japan & 63123 & 72427 \\
\hline Korea & 1500 & 39737 & Singapore & 7007 & 53103 \\
\hline Hong Kong & 18614 & 39503 & Hong Kong & 17816 & 33897 \\
\hline New Zealand & 16084 & 24471 & New Zealand & 8531 & 13066 \\
\hline China & 3939 & 22281 & Malaysia & 12811 & 10897 \\
\hline Singapore & 4580 & 13635 & India & 474 & 7008 \\
\hline Indonesia & 2346 & 12617 & China & 2347 & 6917 \\
\hline Philippines & 3322 & 11521 & Korea & 4152 & 6719 \\
\hline Thailand & 1173 & 10917 & Taiwan & 2136 & 3805 \\
\hline India & 1003 & 9588 & Indonesia & 791 & 3093 \\
\hline Taiwan & 185 & 6899 & Thailand & 721 & 1404 \\
\hline Malaysia & 2808 & 5710 & Philippines & 424 & 822 \\
\hline
\end{tabular}




\begin{tabular}{|c|c|c|c|c|c|}
\hline Pakistan & 1152 & 3078 & Turkey & 388 & 336 \\
\hline Turkey & 997 & 2325 & Pakistan & 0 & 87 \\
\hline \multicolumn{6}{|c|}{ Latin and Central America } \\
\hline Brasilia & 10126 & 98620 & Bermudas & 1773 & 74824 \\
\hline Argentina & 16425 & 49101 & Brasilia & 2255 & 24476 \\
\hline Bermudas & 3194 & 25674 & Argentina & 2629 & 7832 \\
\hline Chile & 5515 & 23740 & Chile & 6185 & 4928 \\
\hline Venezuela & 3792 & 9563 & $\begin{array}{l}\text { Britain Virgins } \\
\text { Islands }\end{array}$ & 370 & 3176 \\
\hline Columbia & 4907 & 8645 & Bahamas & 596 & 2960 \\
\hline Peru & 5122 & 4014 & Panama & 17 & 2815 \\
\hline Panama & 117 & 2419 & Venezuela & 906 & 2719 \\
\hline El Salvador & 40 & 1899 & Cayman Islands & 761 & 2090 \\
\hline Puerto Rico & 142 & 1789 & Columbia & 384 & 1477 \\
\hline Ecuador & 233 & 1670 & $\begin{array}{l}\text { Netherlands } \\
\text { Antilles }\end{array}$ & 462 & 1273 \\
\hline Bolivia & 1135 & 1422 & Barbados & 0 & 737 \\
\hline Cuba & 299 & 823 & Puerto Rico & 0 & 635 \\
\hline \multicolumn{6}{|c|}{ Middle East } \\
\hline Israel & 1732 & 13948 & Israel & 1243 & 10696 \\
\hline Jordan & 26 & 1577 & Saudi Arabia & 2933 & 4714 \\
\hline Kuwait & 6 & 480 & Bahrain & 2816 & 3511 \\
\hline $\begin{array}{l}\text { United Arab } \\
\text { Emirates }\end{array}$ & 0 & 385 & Kuwait & 847 & 1656 \\
\hline Lebanon & 0 & 331 & $\begin{array}{l}\text { United Arab } \\
\text { Emirates }\end{array}$ & 583 & 852 \\
\hline \multicolumn{6}{|c|}{ Africa } \\
\hline South Africa & 3660 & 26016 & South Africa & 8475 & 24817 \\
\hline Egypt & 530 & 4865 & Libyan & 314 & 528 \\
\hline Morocco & 187 & 4513 & Zimbabwe & 20 & 327 \\
\hline Ghana & 53 & 1709 & Egypt & 18 & 284 \\
\hline $\begin{array}{l}\text { Equatorial } \\
\text { Guinea }\end{array}$ & 0 & 993 & Uganda & 0 & 250 \\
\hline Tunisia & 0 & 953 & Ghana & 541 & 141 \\
\hline
\end{tabular}

Source: author's calculations based on data of World Investment Report 2004, 2005.

The activity of transnational companies on the Ukrainian market can be described with the FDI indicator. Our calculations show that in 2003-2004 the significance of FDIs for domestic commodity production has been increasing at a higher rate in the following industries (ISIC Rev.3): 05 - Fishing, operation of fish hatcheries and fish farms; 24 - Manufacture of chemicals and chemical products; O - Other community, social and personal service activities; $\mathrm{G}$ Wholesale and retail trade; repair of motor vehicles, motorcycles and personal 
and household goods; $\mathrm{H}$ - Hotels and restaurants; $\mathrm{K}$ - Real estate, renting and business activities; $\mathrm{N}$ - Health and social work; 19 - Tanning and dressing of leather; manufacture of luggage, handbags, saddlers, harness and footwear; 15 +16 - Manufacture of food products and beverages; manufacture of tobacco products; 20 - Manufacture of wood and products of wood and cork, except furniture; manufacture of articles of straw and plaiting materials.

At the same time, the impact of FDIs on domestic commodity production has been decreasing in such industries as 40 - Electricity, gas, steam and hot water supply; 27+28 - Manufacture of basic metals; manufacture of fabricated metal products, except machinery and equipment ${ }^{3} ; 10+11+12-$ Mining of coal and lignite; extraction of peat; extraction of crude petroleum and natural gas; service activities incidental to oil and gas extraction excluding surveying; mining of uranium and thorium ores; $30+31+32+33$ - Manufacture of office, accounting and computing machinery; manufacture of electrical machinery and apparatus n.e.c; manufacture of radio, television and communication equipment and apparatus; manufacture of medical, precision and optical instruments, watches and clocks; 02 - Forestry, logging and related service activities, $\mathrm{M}-$ Education.

Proceeding from our correlation and regression analysis, we can conclude that in Ukraine, the impact of FDIs on commodity production volumes by industry equalled to $43.5 \%$ (number of observations $-31, \mathrm{R}^{2}=0.435$, F-Test $22.31>7.6$ tabular, $\rho$-value 0.000 ) for 2003 and $64 \%$ (number of observations $-31, \mathrm{R}^{2}=$ 0.640 , F-Test 51.51>7.6 tabular, $\rho$-value 0.000 ) for 2004. The correlation coefficient for the relationship between commodity production by industry and FDIs made 0.621 for 2003 and 0.800 for 2004 (correlation is direct and significant at 0.01 ). The calculated elasticity of commodity production by FDI showed that a $1 \%$-change in FDI resulted in $0.27 \%$ - change in commodity production in 2003 and $0.56 \%$-change in 2004.

From the gravity equation describing Ukraine's foreign trade in goods and services by industry (number of observations - 50 at higher disaggregation of industry data according to ISIC Rev.3), we received the following results for the trade flows-FDIs relationship in 2003-2005 (See Table 8).

\footnotetext{
${ }^{3}$ The money from privatization of the metallurgical state enterprise Kryvorizhstal in 2005, accounted for in the Ukrainian statistics as FDI, remains as state budget non-distributed funds and does not change cardinally the described actual trend for metallurgy and manufacture of metal products.
} 
Table 8. Relationship between Ukraine's FDIs and Foreign Trade in Goods and Services by Industry (Economic Sector), 2003-2005.

\begin{tabular}{|l|l|l|l|l|l|}
\hline Year & $\begin{array}{l}\text { Dependence of } \\
\text { foreign trade } \\
\text { turnover } \\
\text { on FDIs, \% }\end{array}$ & $\begin{array}{l}\text { F-test } \\
\text { (tabular data } \\
7.18 \text { at } 0.01 \\
\text { probability) }\end{array}$ & $\begin{array}{l}\rho \text { - value } \\
\text { less than } \\
0.05 \text { is } \\
\text { considered } \\
\text { significant) }\end{array}$ & $\begin{array}{l}\text { Correlation } \\
\text { coefficient } \\
* * \text { at } 0.01 \\
\text { significance } \\
\text { level }\end{array}$ & $\begin{array}{l}\text { Elasticity of } \\
\text { foreign trade } \\
\text { turnover } \\
\text { by FDI, \% } \\
\text { (change } \\
\text { in foreign } \\
\text { trade turnover/ } \\
1 \% \text {-change in } \\
\text { FDI) }\end{array}$ \\
\hline 2003 & 42.2 & & & & 0.79 \\
\hline 2004 & 20.4 & 12.29 & 0.001 & $0.452^{* *}$ & 0.45 \\
\hline $2005^{*}$ & 17.3 & 10.057 & 0.003 & $0.416^{* *}$ & 0.41 \\
\hline
\end{tabular}

\begin{tabular}{|l|l|l|l|l|l|}
\hline Year & $\begin{array}{l}\text { Dependence of } \\
\text { exports on } \\
\text { FDIs, \% }\end{array}$ & $\begin{array}{l}\text { F-test } \\
\text { (tabular data } \\
7.18 \text { at } 0.01 \\
\text { probability) }\end{array}$ & $\begin{array}{l}\rho \text { - value } \\
\text { (less than } \\
0.05 \text { is } \\
\text { considered } \\
\text { significant) }\end{array}$ & $\begin{array}{l}\text { Correlation } \\
\text { coefficient } \\
* * \text { at } 0.01 \\
\text { significance } \\
\text { level }\end{array}$ & $\begin{array}{l}\text { Elasticity of export } \\
\text { by FDI, \% } \\
\text { (change in exports/ } \\
1 \% \text {-change in FDI) }\end{array}$ \\
\hline 2003 & 29.0 & 19.596 & 0.000 & $0.538^{* *}$ & 0.73 \\
\hline 2004 & 20.4 & 12.306 & 0.001 & $0.452^{* *}$ & 0.48 \\
\hline $2005^{*}$ & 32.0 & 22.577 & 0.000 & $0.566^{* *}$ & 0.57 \\
\hline
\end{tabular}

\begin{tabular}{|l|l|l|l|l|l|}
\hline Year & $\begin{array}{l}\text { Dependence of } \\
\text { imports on } \\
\text { FDIs, \% }\end{array}$ & $\begin{array}{l}\text { F-test } \\
\text { (tabular data } \\
7.18 \text { at } 0.01 \\
\text { probability) }\end{array}$ & $\begin{array}{l}\rho \text { - value } \\
\text { (less than } \\
0.05 \text { is } \\
\text { considered } \\
\text { significant) }\end{array}$ & $\begin{array}{l}\text { Correlation } \\
\text { coefficient } \\
* * \text { at } 0.01 \\
\text { significance } \\
\text { level }\end{array}$ & $\begin{array}{l}\text { Elasticity of import } \\
\text { by FDI, \% } \\
\text { (change in imports / } \\
1 \% \text {-change in FDI) }\end{array}$ \\
\hline 2003 & 52.0 & 50.966 & 0.000 & $0.718^{* *}$ & 0.88 \\
\hline 2004 & 20.4 & 12.265 & 0.001 & $0.451^{* *}$ & 0.45 \\
\hline $2005^{*}$ & 13.1 & 7.22 & 0.01 & $0.362^{* *}$ & 0.37 \\
\hline
\end{tabular}

Note: *receipts from privatization of metallurgical state enterprise Kryvorizhstal not included.

Source: author's calculations based on official data of Ukrainian State Statistics Committee.

Taking into consideration these results, we can assert that FDIs turned Ukraine into an increasingly export-oriented economy. The growth of FDIs in 2005 preconditioned the expansion of Ukrainian exports represented mainly by products of traditional industries (economic sectors). The high growth of 
export volumes in 2005 compared to 2004 was observed in the following industries: 27 - Manufacture of basic metals $-\$ 1644105.09$ thou., I Transport, storage and communications (mainly pipeline transport) $\$ 3650252.9$ thou., 13 - Mining of metal ores - \$552107.7 thou., 01 Agriculture, hunting and related service activities - \$236155.81 thou., 24 Manufacture of chemicals and chemical products - \$223975.9 thou., 02 Forestry, logging and related service activities $-\$ 178049.46$ thou..

At the same time, the influence of FDIs on Ukrainian imports tends to decrease significantly, which leads to decreasing FDI's influence on the Ukrainian foreign trade as a whole. This means that there still is no effect of increasing complementarity between imports of goods and services and FDIs, which under condition of transition - is responsible for structural market changes and saturation of domestic market with differentiated products. Thus, there are no impulses for the economic system of Ukraine to move onto the dimension where economic processes can be explained through the prism of New Trade Theory.

We also calculated the changes in FDIs and foreign trade in the Ukrainian industries for 2004 and 2005. It should be noted that, compared to 2004, the FDIs in Ukraine grew faster in 2005 than did its foreign trade in the following industries (economic sectors): $\mathrm{M}$ - Education - 8.08-fold increase; $30-$ Manufacture of office, accounting and computing machinery - 7.57-fold increase; 27 - Manufacture of basic metals -2.69-fold increase; 13 - Mining of metal ores - 1.64-fold increase; 18 - Manufacture of wearing apparel; dressing and dyeing of fur - 1.32-fold increase; 36 - Manufacture of furniture; manufacturing n.e.c.- 1.1-fold increase; 24 - Manufacture of chemicals and chemical products - 1.09-fold increase; 28 - Manufacture of fabricated metal products, except machinery and equipment -1.07 -fold increase.

We can hope that the intensification of economic liberalization in Ukraine and implementation of real reforms in the course of its European economic integration will increase in the future the role of FDIs in explaining the Ukrainian industrial structure and foreign trade flows. The preconditions for revealing the postulates of the New Trade Theory would be formed especially in the industries with differentiated production characterized simultaneously by high foreign direct investments and international trade openness (See selected cells in Table 9). As for Ukraine, this is currently true for the following industries: $17+18$ - Manufacture of textiles; manufacture of wearing apparel; dressing and dyeing of fur, $\mathrm{G}$ - Wholesale and retail trade; repair of motor vehicles, motorcycles and personal and household goods; 20 - Manufacture of wood and products of wood and cork, except furniture; manufacture of articles of straw and plaiting materials; 25 - Manufacture of rubber and plastics products; 36+ 37 - Manufacture of furniture; manufacturing n.e.c.; recycling; 24 - Manufacture of chemicals and chemical products; 19 - Tanning and dressing of leather; manufacture of luggage, handbags, saddlers, harness and footwear. 
Table 9. Investment and Trade Openness of Ukrainian Industries (Economic Sectors), 2003-2004.

\begin{tabular}{|c|c|c|c|c|c|c|}
\hline $\begin{array}{l}\text { Industry (Economic Sector) } \\
\text { ISIC Rev. } 3\end{array}$ & \multicolumn{3}{|c|}{$\begin{array}{l}\text { FDI Openness } \\
\text { (FDI/Output), \% }\end{array}$} & \multicolumn{3}{|c|}{$\begin{array}{l}\text { Trade Openness (Foreign } \\
\text { Trade Turnover in Goods } \\
\text { and Services/Output), } \%\end{array}$} \\
\hline Year & 2003 & 2004 & Rank & 2003 & 2004 & Rank \\
\hline All economy & 8.30 & 7.75 & & 64.54 & 64.02 & \\
\hline $\begin{array}{l}01 \text { Agriculture, hunting and } \\
\text { related service activities }\end{array}$ & 4.69 & 4.66 & 22 & 8.04 & 0.06 & 30 \\
\hline $\begin{array}{l}02-\text { Forestry, logging and } \\
\text { related service activities }\end{array}$ & 3.26 & 2.77 & 26 & 58.65 & 0.02 & 31 \\
\hline $\begin{array}{l}05 \text { - Fishing, operation of fish } \\
\text { hatcheries and fish farms; service } \\
\text { activities incidental to fishing }\end{array}$ & 0.87 & 4.59 & 24 & 40.30 & 13.02 & 28 \\
\hline $\begin{array}{l}10 \text { - Mining of coal and lignite; } \\
\text { extraction of peat; } \\
11 \text { - Extraction of crude } \\
\text { petroleum and natural gas; } \\
\text { service activities incidental to oil } \\
\text { and gas extraction excluding } \\
\text { surveying; } \\
12 \text { - Mining of uranium and } \\
\text { thorium ores. }\end{array}$ & 2.32 & 1.89 & 28 & 17.49 & 20.98 & 22 \\
\hline $\begin{array}{l}13 \text { - Mining of metal ores; } \\
14 \text { - Other mining and quarrying. }\end{array}$ & 9.67 & 5.13 & 20 & 51.12 & 55.19 & 15 \\
\hline $\begin{array}{l}15 \text { - Manufacture of food } \\
\text { products and beverages; } \\
16 \text { - Manufacture of tobacco } \\
\text { products. }\end{array}$ & 11.12 & 11.23 & 10 & 34.00 & 32.64 & 17 \\
\hline $\begin{array}{l}17 \text { - Manufacture of textiles; } \\
18 \text { - Manufacture of wearing } \\
\text { apparel; dressing and dyeing } \\
\text { of fur }\end{array}$ & 17.55 & 16.76 & 5 & 250.71 & 237.64 & 2 \\
\hline $\begin{array}{l}19 \text { - Tanning and dressing of } \\
\text { leather; manufacture of } \\
\text { luggage, handbags, saddlers, } \\
\text { harness and footwear }\end{array}$ & 8.39 & 8.67 & 15 & 123.45 & 119.65 & 4 \\
\hline $\begin{array}{l}20 \text { - Manufacture of wood and } \\
\text { products of wood and cork, } \\
\text { except furniture; manufacture } \\
\text { of articles of straw and plaiting } \\
\text { materials }\end{array}$ & 24.44 & 24.21 & 4 & 66.83 & 65.64 & 11 \\
\hline $\begin{array}{l}21 \text { - Manufacture of paper and } \\
\text { paper products }\end{array}$ & 10.71 & 7.85 & 16 & 94.43 & 74.12 & 10 \\
\hline
\end{tabular}




\begin{tabular}{|c|c|c|c|c|c|c|}
\hline $\begin{array}{l}22-\text { Publishing, printing and } \\
\text { reproduction of recorded media }\end{array}$ & 9.21 & 9.09 & 13 & 26.69 & 20.51 & 23 \\
\hline $\begin{array}{l}23 \text { - Manufacture of coke, } \\
\text { refined petroleum products and } \\
\text { nuclear fuel }\end{array}$ & 4.79 & 3.91 & 25 & 46.32 & 60.06 & 14 \\
\hline $\begin{array}{l}24 \text { - Manufacture of chemicals } \\
\text { and chemical products }\end{array}$ & 7.45 & 9.93 & 12 & 82.61 & 92.64 & 6 \\
\hline $\begin{array}{l}25 \text { - Manufacture of rubber } \\
\text { and plastics products }\end{array}$ & 16.57 & 12.26 & 8 & 70.14 & 76.76 & 8 \\
\hline $\begin{array}{l}26 \text { - Manufacture of other non- } \\
\text { metallic mineral products }\end{array}$ & 10.04 & 9.04 & 14 & 30.90 & 28.24 & 18 \\
\hline $\begin{array}{l}27 \text { - Manufacture of basic } \\
\text { metals; } \\
28 \text { - Manufacture of fabricated } \\
\text { metal products, except } \\
\text { machinery and equipment. }\end{array}$ & 3.25 & 2.35 & 27 & 73.48 & 64.36 & 13 \\
\hline $\begin{array}{l}29 \text { - Manufacture of machinery } \\
\text { and equipment n.e.c. }\end{array}$ & 7.49 & 5.85 & 18 & 58.24 & 65.51 & 12 \\
\hline $\begin{array}{l}30 \text { - Manufacture of office, } \\
\text { accounting and computing } \\
\text { machinery; } \\
31 \text { - Manufacture of electrical } \\
\text { machinery and apparatus n.e.c; } \\
32 \text { - Manufacture of radio, } \\
\text { television and communication } \\
\text { equipment and apparatus; } \\
33 \text { - Manufacture of medical, } \\
\text { precision and optical } \\
\text { instruments, watches and clocks. }\end{array}$ & 8.99 & 5.84 & 19 & 59.48 & 45.09 & 16 \\
\hline $\begin{array}{l}34 \text { - Manufacture of motor } \\
\text { vehicles, trailers and semi- } \\
\text { trailers; } \\
35 \text { - Manufacture of other } \\
\text { transport equipment }\end{array}$ & 11.58 & 7.81 & 17 & 84.28 & 79.05 & 7 \\
\hline $\begin{array}{l}36 \text { - Manufacture of furniture; } \\
\text { manufacturing n.e.c.; } \\
37 \text { - Recycling }\end{array}$ & 13.05 & 11.32 & 9 & 59.69 & 76.30 & 9 \\
\hline $\begin{array}{l}40 \text { - Electricity, gas, steam and } \\
\text { hot water supply }\end{array}$ & 1.55 & 0.64 & 30 & 17.71 & 18.15 & 24 \\
\hline $\mathrm{F}-$ Construction $(45)$ & 4.90 & 4.65 & 23 & 7.87 & 10.73 & 29 \\
\hline $\begin{array}{l}\text { G - Wholesale and retail trade; } \\
\text { repair of motor vehicles, } \\
\text { motorcycles and personal and } \\
\text { household goods }(50,51,52)\end{array}$ & 13.67 & 16.16 & 6 & 126.70 & 140.90 & 3 \\
\hline
\end{tabular}




\begin{tabular}{|l|r|r|r|r|r|r|}
\hline H - Hotels and restaurants (55) & 29.19 & 35.85 & 2 & 18.41 & 22.69 & 21 \\
\hline $\begin{array}{l}\text { I - Transport, storage and } \\
\text { communications (60, 61, 62, 63, } \\
\text { 64) }\end{array}$ & 5.12 & 5.09 & 21 & 49.30 & 22.89 & 20 \\
\hline $\begin{array}{l}\text { J - Financial intermediation } \\
\text { (65,66) }\end{array}$ & 65.02 & 25.51 & 3 & 24.24 & 14.21 & 27 \\
\hline $\begin{array}{l}\text { K - Real estate, renting and } \\
\text { business activities (70, 71, 72, }\end{array}$ & 10.21 & 11.16 & 11 & 138.43 & 106.22 & 5 \\
$\begin{array}{l}73,74) \\
\text { L - Public administration and } \\
\text { defence; obligatory social } \\
\text { security (75) }\end{array}$ & 0.00 & 0.05 & 31 & 1176.3 & 1184.5 & 1 \\
\hline M - Education (80) & 1.62 & 1.49 & 29 & 15.77 & 15.96 & 26 \\
\hline N - Health and social work (85) & 40.70 & 44.72 & 1 & 24.49 & 23.66 & 19 \\
\hline $\begin{array}{l}\text { O - Other community, social and } \\
\text { personal service activities (90, } \\
\text { 91, 92, 93) }\end{array}$ & 12.65 & 15.62 & 7 & 12.03 & 17.37 & 25 \\
\hline
\end{tabular}

Source: author's calculations based on official data of Ukrainian State Statistic Committee.

\section{Conclusions}

The multidimensional and systemic principles of the New Trade Theory can be revealed in the course of deepening globalization and integration processes in the modern world economy. Opening-up of countries' economies for international competition and their simultaneous aspiration to converge with their main trade partners become the drivers of economic development and growth of well-being under the new conditions. It is easier for a group of countries that have historically built the foundation for their close collaboration with one another comparing to third countries and currently have mutual economic and geopolitical values to realize these steps. Today, Ukraine is at the cross-roads between the two geopolitically different, but at the same time important for its development, regional economic blocks -- the European and the Eurasian economic areas. This fact essentially complicates the realization of rapid transformation of Ukraine's traditional international trade and economic development paradigm into a qualitatively new one, based on the New Trade Theory principles. The incompatibility of goals of the European and the Eurasian economic blocks becomes especially apparent now, when Russia headed for militarization of its economy and Belarus just refused again to form an open society and realize western values. These circumstances will impede American and western European transnational (multinational) corporations, as main carriers of capital and differentiated products to the recipient countries in transition, in their attempt to create the "societies of obedient consumers" in these countries. 
In this situation, Ukraine can choose between the two alternative regional economic blocks for its full integration -- either the European Union or the Single Economic Area. At that, Ukraine has to take into consideration not the ill-founded political arguments, not the Ukraine's unnatural tendency to economic growth based on the inefficient economic model and undeniably short-lived in nature, but the model of economic development that would objectively be capable of ensuring higher welfare of the nations in the modern world economy. In view of all the aforementioned theoretical postulates and empirical findings, we can conclude that Ukraine, as a country in transition, should commit itself to formation of the model of economic development based on the New Trade Theory postulates. This model will better exert itself if Ukraine intensifies its integration processes within the European economic area. At the same time, we should keep in mind that, while elaborating such a far-reaching economic development model, Ukraine must use its potential immediately and most efficiently within the scope of Traditional Trade Theory, realizing the principle of comparative advantage in its production and trade relations with the EU countries.

\section{References}

Anderson, J. and J. Neary (1996) "A New Approach to Evaluating Trade Policy", Review of Economic Studies, vol. 63(1), no. 214, pp. 107-125.

Aquino, A. (1978) "Intra-Industry Trade and Inter-Industry Specialization as Concurrent Sources of International Trade in Manufactures", Weltwirtschaftliches Archiv, vol. 114, pp. 275-296.

Balassa, B. (1986) "Intra-Industry Specialization: A Cross-Country Analysis", European Economic Review, vol. 30, pp. 27-42.

Bardhan, P. (1995) "The Contributions of Endogenous Growth Theory to the Analysis of Development Problems: An Assessment", in Behrman, J. and Srinivasan T. N. (eds.), Handbook of Development Economics, Elsevier Science, Amsterdam.

Bergstrand, J. (1989) "The Generalized Gravity Equation, Monopolistic Competition and the Factor-Proportions Theory of International Trade", Review of Economics and Statistics, vol. 71, pp. 143-153.

Bergstrand, J. (1983) "Measurement and Determinants of Intra-Industry International Trade", in P.K.M. Tharakan, ed., Intra-Industry Trade: Empirical and Methodological Aspects, North- Holland, Amsterdam. 
Bhattacharjea, A. (1995) "Strategic Tariffs and Endogenous Market Structures: Trade and Industrial Policies under Imperfect Competition", Journal of Development Economics, vol. 47, no. 2, pp. 287-312.

Brainard, S. and D. Martimort (1997) "Strategic Trade Policy with Incompletely Informed Policymakers", Journal of International Economics, vol. 42, no. 1-2, pp. 33-66.

Brainard, S. (1993) "A Simple Theory of Multinational Corporations and Trade with a Trade-off between Proximity and Concentration", NBER Working Paper, no 4269.

Brander, J. and B. Spencer (1985) "Export Subsidies and International Market Share Rivalry”, Journal of International Economics, vol. 16, pp. 83-100.

Brander, J. (1995) "Strategic Trade Policy", in G. Grossman and K. Rogoff (eds.), Handbook of International Economics, Vol. III, North-Holland: Amsterdam, pp. 1395-1455.

Brenton, P., Di Mauro, F. and Lucke, M. (1999) "Economic Integration and FDI: An Empirical Analysis of Foreign Investment in the EU and in Central and Eastern Europe", Empirica, (26), pp.95-121.

Carrillo, C. and Li, C.A. (2002) "Trade Blocks and the Gravity Model: Evidence from Latin American Countries", University of Essex, Discussion Paper.

Coe, D. et al (1995) "North-South R\&D Spillovers", CEPR Discussion Paper, no 1133, Centre for Economic Policy Research, London.

Eaton, J. and G. Grossman (1986) "Optimal Trade and Industrial Policy under Oligopoly”, Quarterly Journal of Economics, 101, pp. 603-607.

Eaton, J. and S. Kortum (2002) "Technology, Geography and Trade", Econometrica, vol. 70, no. 5 (Sept., 2002), pp. 1741-1779.

Ekholm, K. (1997) "Factor Endowments and the Pattern of Affiliate Production by Multinational Enterprises", CREDIT Working Paper no. 97/19, University of Nottingham.

Evenett, S. and W. Keller (1998) "On the Theories Explaining the Success of the Gravity Equation”, NBER Working Paper, No. 6529.

Falvey, R. (1981) "Commercial Policy and Intra-Industry Trade", Journal of International Economics, vol. 11, pp. 495-511. 
Feenstra, R., J. Markusen and A. Rose (2001) "Using the Gravity Equation to Differentiate Among Alternative Theories of Trade", Canadian Journal of Economics, vol. 1, May, pp. 430-447.

Fontagné, L. and Freudenberg, M. (1997) "Intra-Industry Trade: Methodological Issues Reconsidered”, CEPII, document de travel, No. 97-01.

Fritsch, M., Th.Wein, H-J. Ewers (2003) "Marktversagen und Wirtschaftspolitik", Verlag Franz Vahlen, München, 5.Auflage.

Fuerst, T. and K. Kim (1997) "Two Part Trade Policy under Imperfect Competition", Review of International Economics, vol. 5, no. 1, pp. 63-71

Grossman, G. and E. Helpman (1991) "Innovation and Growth in the Global Economy", MIT Press, Cambridge.

Helpman, E. and P. Krugman (1985) "Market Structure and Foreign Trade", MIT, Press, Cambrige.

Helpman, E. (1998) "The Size of Regions", in D. Pines, E. Sadka, and I.Zilcha (eds.), Topics in Public Economics: Theoretical and Applied Analysis. (Cambrige: Cambrige University Press).

Hirschman, A. (1958) “The Strategy of Economic Development", new Haven: Yale University Press.

Ionascu, D. and K. Šigić ( 2001) "Strategic Trade Policy and Mode of Competition: Symmetric. versus Asymmetric Information", CERGE-EI, Working Paper, no. 174.

Kandogan, Y. (2003) "Intra-industry Trade of Transition Countries: Trends and Determinants", The William Davidson Institute, University of Michigan Business School, Working Paper, no. 566, May 2003.

Klüver, A. und G. Rübel (1998) "Räumliche Industriekonzentration und die komparativen Vorteile von Ländern - eine empirische Studie der Europäischen Union", Die Gruppe der volkswirtschaftlichen Professoren der Wirtschaftswissenschaftlichen Fakultät der Universität, Disskussionsbeitrag, Passau, Nr. V-5-98, Passau 1998.

Konchyn V. (2005). "Alternatyvni shlyahy rozvytku mizhnarodnoyi tovarnoyi spetsializatsiyi Ukrainy $\mathrm{v}$ contexti yiyi yevropeyskoyi integratsiyi”, in: Zbirnyk naukovyh prats "Svitohospodarski priorytety Ukrainy", Institut Economicy NAN Ukrainy, Kiev, 2005. 
Krugman, P. (1979) "Increasing Returns, Monopolistic Competition, and International Trade", Journal of International Economics, November 1979, vol. 9, No. 4, pp. 469-479.

Krugman, P. (1985) "Increasing Returns and the Theory of International Trade", NBER Working Paper, no. 1752, November.

Krugman, P. (1991) "Increasing Returns and Economic Geography", Journal of Political Economy, University of Chicago Press, vol. 99(3), pp. 483-499.

Krugman, P. and A. Venables (1993) "Integration, Specialization and Adjustment", CEPR Discussion Papers no. 886.

Leahy, D. and J. Neary (1997) "Public policy towards R\&D in oligopolistic industries", American Economic Review, no. 87, pp. 642-662.

Lee, N. (1992). "Market Structure and Trade in Developing Countries", in: Helleiner (ed).

Lucas, R. (1988) "On the Mechanics of Economic Development", Journal of Monetary Economics, no. 22, pp. 3-42.

Markusen, J. (1984) "Multinationals, Multi-plant Economies, and the Gains from Trade", Journal of International Economics, 16, 3-4, pp. 205-226.

Markusen J. (1998) "Multinational firms, location and trade", World Economy 21, pp. $737-756$.

Markusen, J. and A. Venables (1998), "Multinational Firms and the New Trade Theory", Journal of International Economics, 46, 2, pp. 183-203.

Markusen, J. and K. Maskus (1999) "Multinational Firms: Reconciling Theory and Evidence", National Bureau of Economic Research Working Paper, no. 7163.

Midelfart Knarvik, K-H et al. (2000) "Comparative Advantage and Economic Geography: Estimating the Location of Production in the EU", CEPR Discussion paper, no. 2618.

Muchielli, J. and B. Burgenmeier (1991) "Multinationals and Europe 1992: Strategies for the future", London, Routledge, 1991

Myrdal, G. (1957) "Economic Theory and Under-developed Regions", London, Duckworth, 1957. 
Rauch J. (1999) "Networks versus Markets in International Trade", Journal of International Economics, vol. 48, pp. 7-35.

Redding, S. and A. Venables (2000) "Economic Geography and International Inequality”, CEPR Discussion Paper no. 2568.

Ricci, L. (1996) "Geography and Comparative Advantage", Sonderforschungsbereich 178 "Internationalisierung der Wirtschaft. Diskussionsbeiträge, Konstanz, Serie II- Nr.321, Oktober.

Ricci, L. (1997) “A Ricardian Model of New Trade and Location Theory", Journal of Economic Integration, vol. 12 (March), pp. 47-61.

Ruttan, V. (1998) "The new growth theory and development economics: A survey", Journal of development studies, vol. 35, no. 2, pp. 1-26.

Pissarides, C. (1997) "Learning by Trading and the Returns to Human Capital in Developing Countries", The World Bank Economic Review, Vol. 11, No. 1, P. 17-21. 